\title{
38. A New Permian Species of Pseudophillipsia (Trilobita) with Spatulate Genal Spines*)
}

\author{
By Teiichi Kobayashi, M. J. A., and Takashi HamadA \\ University of Tokyo \\ (Communicated April 12, 1980)
}

Phillipsiids and brachymetopids are two groups of trilobites survived until the Permian Period. Therefore their high specialization before annihilation is of special interest for palaeontologists, as explicitly demonstrated by Cretaceous heteromorphs for ammonoids (Matsumoto, 1967). Upper Permian Iranaspidion sagittalis Kobayashi and Hamada, 1978 from Iran would be such an example among trilobites. In its glabella a short sagittal furrow cuts into the main lobe and the basal lobe is binodose. In the axial lobe of its pygidium a median slit and a median ridge on the bottom are present in the rear terminus. Goldring (1957) has already called attention to the terminal septum in Pseudophillipsia lipara and some other species of Pseudophillipsia. The combination of these specialities in Iranaspidion sagittalis is really extraordinary.

A new species of Pseudophillipsia described here from the Middle Permian of Kamiyatsuse also has a median slit. It bears several significant characteristics among which the large spatulate genal spines are quite unique among the known trilobites. The spine is almost as long as the thorax, subvertical and expanding forward from the terminal point. In the lateral view the upper margin is almost straight and the lower margin broadly arcuate. Thus it attains nearly as high as the thorax. In the dorsal view the median furrow is gradually widening forward on the genal spine. The spines continue to the unusually erect lateral and frontal borders of the cephalon. These spines and borders must have been the outer wall of the dorsal shield for selfguard.

It is further noteworthy in the pygidium of this species that the axial rings are about twice the pleural ribs beside the fulcral processbearing anterior riblet which is the anterior band of the first pleuron. The double number of the axial rings is probably due to the bipartation of a tergite into two rings in the pygidium.

Pseudophillipsia (Pseudophillipsia) spatulifera, sp. nov.

Figs. 1-3

*) Studies of Japanese Trilobites and Associated Fossils-20. 
Description:-Cephalon subtrigonal, but well rounded in front of glabella, surrounded by thick marginal border, forming salient crest on lateral and anterior sides and involving profound marginal furrow; lateral and posterior borders combined at genal angle whence issues a large spatulate genal spine nearly as far as thoracic length; lateral and posterior marginal furrows confluent with each other at the angle; median furrow extending therefrom into narrow summit level of genal spine. Glabella somewhat larger than cheek, composed of a suboval main lobe and a trisected preoccipital lobe beside large neck ring; main lobe provided with three pairs of lateral lobes in form of prominent tubercles; preoccipital lobe clearly divided into a relatively broad median lobe and a pair of basal lobes produced

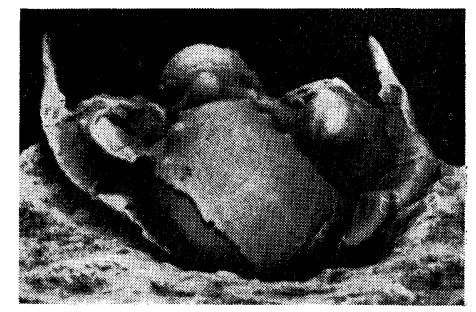

$1 \mathbf{a}$

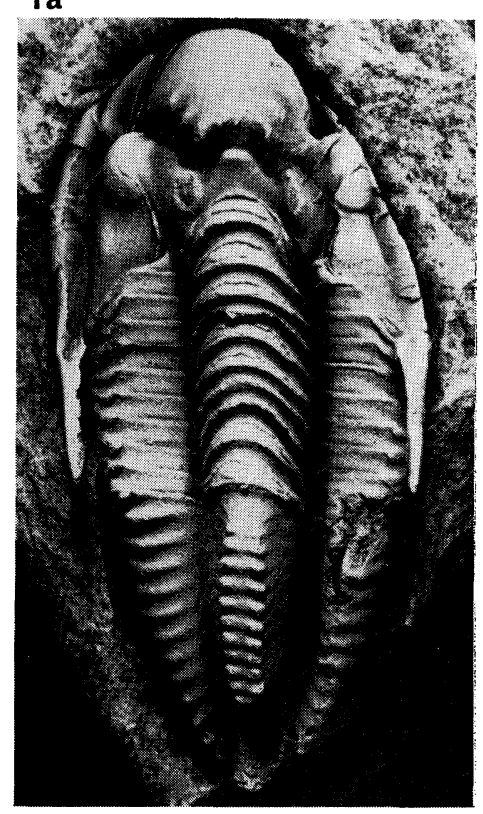

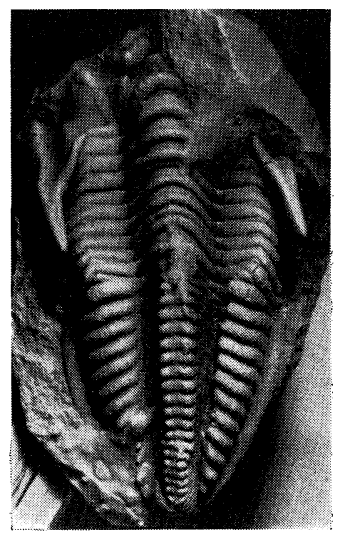

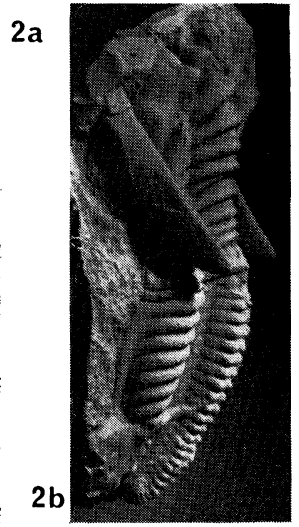

2c

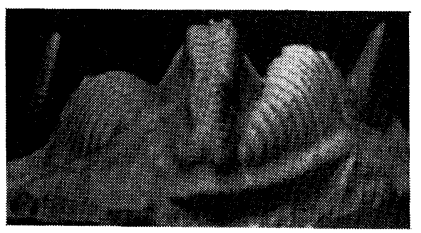

$2 \mathbf{d}$

3
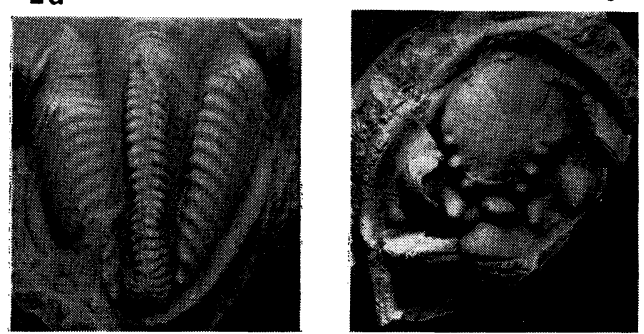

Figs. 1-3. 1, a, b: Dorsal and frontal views of the holotype (internal mold). $\times 2.28$. 2, a, b: Dorsal and left lateral views of the same (external replica). $\times 1.57$. $c, d$ : Rear and dorsal views of pygidium of the holotype specimen showing the median slit at the caudal tip. $c, \times 2.25 ; \mathrm{d}, \times 1.78$. 3 : Dorsal view of the paratype cephalon (external replica). $\times 1.43$. 
upward and backward; preoccipital and occipital furrows well developed; occipital ring very large, subtrapezoidal, sloping forward from tuberculate posterior margin; median tubercle absent on the ring. Fixed cheek narrow; eyes large, prominent, extending from middle lateral furrow to part of basal lobe, as wide as cheek roll; palpebral lobe semicircular, sloping inward rather steeply; facial sutures divergent from eyes as far as parallels through eye-limits; sutures subparallel to each other for short distance behind eyes and then crossing posterior cheek border diagonally from median point of its anterior margin.

Thorax a little shorter than the cranidium, composed of nine segments, more or less broadened in mid-length; axial lobe nearly as wide as pleural lobe; axial ring strongly convex; pleuron suddenly geniculate, subhorizontal and transversal on axial side, but steeply sloping down and extending postero-laterally from geniculation where a small but distinct fulcral process is present; a row of tubercles alined on posterior ring margin.

Pygidium a little longer than cephalon, parabolic in outline, or subtrigonal but well rounded at three angles, slightly longer than wide, widest at a quarter behind articulating margin. Axial lobe nearly as wide as pleural lobe, prominent, trapezoidal in cross section, composed of about 25 axial rings, separated from one another by deep ring furrows, tapering backward slowly, but abruptly near terminus where it is overhanging; summit of each ring divided into a pair of nodes and a median flat interval; its lateral slope subvertical, and its lateral quadrate terminus slanting down to axial furrow; a few rear axial rings excavated on top in form of median slit. Pleural lobe limited by relatively weak axial furrow, sloping inward gently in adaxial part and strongly arching down in abaxial part, divided into 12 ribs by profound furrows, ornamented by a row of small tubercles along posterior margin; process-bearing riblet present along anterior margin. Marginal border of moderate breadth, depressed, separated from ribbed part by shallow furrow, and gently warped up behind axial lobe.

Observation:-In this species the basal lobe of the glabella is protruded upward and backward and more or less pointed, like the same lobe of Neoproetus (Triproetus) subovalis Kobayashi and Hamada, 1979, from the Lower Permian of Thailand. In Iranaspidion sagittalis Kobayashi and Hamada, 1978, from the Upper Permian of Iran the basal lobe is binodose and each node somewhat pointed on the top in this species. Its pygidium has the rear slit on the axial lobe like this species as well as Ps. sumatrensis and some others of the same genus (Golding, 1957). These must be the indication of 
phylogerontic specialization.

The genal spines are rather seldom to be preserved in Pseudophillipsia, but it is known that the spine is moderate in length in $P s$. sumatrensis. In certain species of Ps. (Carniphillipsia), particularly in Ps. (C.) ogivalis javonikensis G. and R. Hahn and Ramovš, 1977, from the Upper Carboniferous of Karawaken, the spines are very long. The spines of the present species is quite unusual in that they are long, large and spatulate in lateral view and projected backward on the two sides of the thorax like its lateral walls. Insofar as the authors are aware, there is no comparable genal spines among the known trilobites.

In the thorax an axial ring is divided into a less convex somewhat larger half-ring and a more convex slightly narrower annulus, as seen in the first and ninth segments. The pleurae have a fulcral process at each geniculation or shortly on its adaxial side. It is small and prominent. In comparison to the posterior band of the pleuron the anterior band is very narrow but distinct on the adaxial side of the process.

In the pygidium the process-bearing anterior band is represented by a riblet along the anterior margin. The succeeding 12 ribs are considerably broader than the riblet. The axial rings are just about twice the pleural ribs plus the first riblet in number. This suggests that the axial ring is bipartate in the pygidium.

Comparison:-The subtrigonal outline of the cephalon, salient crest of marginal border, unusually well developed marginal furrow, large spatulate genal spine, three pairs of nodose lateral lobes, extraordinarily prominent basal lobe, very large eyes and neck ring on the cephalon, and the bipartation of the binodose axial rings and the terminal slit of the axial lobe on the pygidium are quite distinctive of this species.

This species is evidently more allied to Pseudophillipsia obtusicauda than Ps. sumatrensis in the glabellar configuration and the binodose axial rings of the pygidium, but the outline of its pygidium agrees better with $P$ s. sumatrensis than the other, insofar as can be judged from the illustrations of these two species by Fliegel (1901), Frech (1911), Goldring (1957), G. Hahn and Brauckmann (1975), and others.

Because the cephalon of Ps. obtusicauda is imperfectly preserved in the holotype specimen, it is difficult to make its exact comparison with this species. The occurrences of Pseudophillipsia allied to Ps. obtusicauda and other species are reported by Endo and Matsumoto (1962), Jimbo (1966), Araki and Koizumi (1968), Koizumi and Sasaki (1978) and Koizumi et al. (1979) from various localities in Japan, but their exact identification still remains for detailed future 
studies.

Occurrence:-Kamiyatsuse, Kesen'numa City, Miyagi Prefecture, Northeast Honshu; late Middle Permian Kanokura Formation.

Acknowledgement. Finally the authors express their cordial thanks to Dr. F. Kojima for the privilege of studying such an interesting trilobite specimen.

\section{References}

Araki, H., and Koizumi, H. (1968): Permo-Carboniferous trilobites from the Kitakami mountains. Chigaku-Kenkyu, 19, 151-158, 212-224.

Endo, R., and Matsumoto, E. (1962) : Permo-Carboniferous trilobites from Japan. Sci. Rep. Saitama Univ., ser. B, 4(2), 149-172, pls. 8-10.

Fliegel, G. (1901): Ueber oberkarbonische Faunen aus Ost- und Süd-Asien. Palaeontogr., 48, 91-136, pls. 6-8.

Frech, F. (1911): Die Dyas. Dyasiches Kohlenschichten von Lo-Ping (Prov. Kiangsi). In Richthofen's China (Berlin), 5, 1-289, 13 pls.

Goldring, R. (1957) : Pseudophillipsia (Tril.) from Permian (or Uralian) of Oman, Arabia. Senck. Leth., 38(3/4), 195-210, pl. 1.

Hahn, G., and Brauckmann, V. (1975) : Revision zweier Trilobiten aus dem Perm Asiens. Geol. et Palaeont., 9, 117-124.

Hahn, G. and R., and Ramovš, A. (1977) : Trilobiten aus dem Ober-Karbon (Gshelium) der Karawaken/Slowenien. Geol. et Palaeont., 11, 135-160, 2 pls.

Jimbo, Y. (1966) : Trilobites from the Middle Permian Kanokura Formation. J. Geol. Soc. Japan, 72, 593-594.

Kobayashi, T., and Hamada, T. (1978) : Two new Upper Permian trilobites from Iran. Proc. Japan Acad., 54B, 157-162.

- (1979) : Permo-Carboniferous trilobites from Thailand and Malaysia. Geol. Palaeont. SE Asia, 20, 1-21, pls. 1-3.

Koizumi, H., and Sasaki, K. (1978) : Permian trilobites from Omote-Matsukawa and Myoga-zawa, Kesen'numa City, Miyagi Prefecture. Chigaku-Kenkyu, 29, 297-311.

Koizumi, H., Yoshino, T., and Kojima, H. (1978) : Occurrence of Permian trilobite Pseudophillipsia from Yamasuge, Kuzuu-Machi, Tochigi Prefecture. ChikyuKagaku, 33(6), 353-354, pl. 1.

Matsumoto, T. (1967): Evolution of the Nostoceratidae (Cretaceous heteromorph ammonoids). Mem. Fac. Sci., Kyushu Univ., ser. D, 18, 331-347, pls. 18-19. 